\title{
Pre-Service English as a Foreign (EFL) Teachers' Intercultural Communicative Competence Development During Their Study Abroad Program
}

\author{
Puput Arfiandhani ${ }^{1 *}$, Fatona Suraya ${ }^{2}$
}

\author{
${ }^{1}$ Universitas Muhammadiyah Yogyakarta \\ ${ }^{2}$ Universitas Negeri Semarang \\ * Email: puput.arfiandhani@fpb.umy.ac.id
}

\begin{abstract}
Recent years have witnessed the surge of the number of students who partake in various study abroad programs. As a result, more students are exposed to international and intercultural experiences, leading to increased intercultural competence. This exposure is especially significant for language teachers as they are at the frontline in exposing their students to foreign languages and cultures. The present study investigates pre-service English as A Foreign Language (EFL) teachers' study abroad experiences. More specifically, the present study investigates pre-service teachers' intercultural competence development during their study abroad programs. A qualitative research approach is applied. In-depth interviews were done with three participants to collect the data. The research finding may contribute towards a better understanding of Indonesian pre-service teachers' intercultural competence development in their study abroad programs.
\end{abstract}

\section{Keywords: EFL, Pre-Service Teachers, Study Abroad, Intercultural Competence}

\section{INTRODUCTION}

The number of university students who participated in study abroad programs has increased over the last decade. One of the factors that may help raise the number could be that study abroad programs have been widely believed to improve and develop language skills [1]. Additionally, the study abroad programs increase depends on the student's economic background [2]. Students who want to participate need to prepare themselves mentally and financially. They need to pay for the dorm, for the study program, and life there. As the world's economic condition has generally improved and travel costs have become more affordable, interest in study abroad programs may increase.

Studies on study abroad programs and intercultural communicative competence have suggested that study abroad programs positively impact its participants. This situation could be the case since study abroad programs involve learning about language and culture [3]. There are several positive effects for students studying abroad, including increased intercultural competence, problem-solving, individual and social intercultural competence and strategic, intercultural competence. According to Brown (2009), study abroad experiences may bring several benefits, such as improving foreign language proficiency, developing cultural knowledge, interpersonal maturity, and increasing international interest and concern [4]. Additionally, Larzén-Östermark mentioned that with proper planning, study abroad programs could provide students with intercultural awareness, prepare students for graduate study, enhance oral proficiency, and motivate students to pursue further language study and travel abroad [5]. Study abroad program can provide opportunities for English teachers to reflect and learn about their own competences [6]. 
Study abroad programs could potentially be helpful to develop pre-service English teachers' intercultural communicative competence. The language teacher's role that includes developing skills, attitudes, and awareness of values just as much as developing knowledge of a particular culture or country could be facilitated through their study abroad experiences. Observing the potential benefits that study abroad experiences offer in developing pre-service English teachers' intercultural competence, the present study aims at investigating Indonesian pre-service teachers' intercultural competence development in their study abroad programs.

\section{LITERATURE REVIEW}

\section{$2.1 \quad$ Intercultural Communicative Competence}

Intercultural communicative competence (ICC), or has been interchangeably referred to as intercultural competence, has been an essential part of foreign language learning. Since foreign languages, including English, a lingua franca, may mediate interactions across cultures, Timpe (2014) asserted that language skills are significant parts that contribute to successful intercultural interaction. In line with this, Wilkinson suggested that intercultural competence has been acknowledged as an essential skill set to adapt to diverse cultures [1]. Drawing on Byram's intercultural communicative competence (1997) [7], Arfiandhani's (2017) findings on language teachers' teaching abroad experiences suggested that their intercultural attitudes, knowledge and cross-cultural awareness improved during their abroad experience [8].

Kramsch (1998) suggested that language and culture are intertwined on which language embodies interlocutors' cultural values, reflecting cultural reality [9]. It is crucial to integrate intercultural communicative competence into language learning drawing from the close relationship between culture and language. According to Byram, intercultural competence can be defined as mediating meanings and communication across cultures [7]. Bouchard (2017) defined intercultural communicative competence as "the ability to deal with difference, an ability which in large part entails managing one's value judgment when facing difference."[10].
Several models of ICC have been developed over the years. One of the notable models is the one developed by Byram (1997) [7]. The model proposes that intercultural communicative competence includes five aspects: intercultural attitudes, critical cultural awareness, skills of discovery and interaction, skills of interpreting and relating and knowledge of their social groups and their products and practices. This seminal work is not explicitly developed for foreign language teachers. The widely implemented model is developed for language learners in general.

Two decades after Byram's ICC model, another model, which is specifically designed for English language teachers, is developed by Bouchard (2017) [10]. His model is developed based on the context of Japanese junior high school teachers and learners. His model includes three main components of ICC: critical thinking, language and culture and culture components.

Byram's (1997) [7] and Bouchard's (2017) [10] models of ICC have provided insights on components that make a successful intercultural interaction. In short, skills such as those components are necessary to be nurtured in language classes. Therefore, language classes will be more effective in promoting intercultural interaction among students.

\subsection{Study Abroad}

The study abroad program becomes one of the programs offered by the university to the student. There are many different programs of study, and there are many destinations to study abroad. The student can choose the program that suitable for them.

Study abroad is a program that requires students to spend at least one semester at another university during their studies. The students study abroad or in another country for several semesters during their studies. That means the students will come back to their country to study at their university after studying abroad. During the study abroad program, the student will live in a dorm or stay with a local host family.

In another research study abroad is called short term study. Study abroad programs can last anywhere from two weeks up to a year, depending on the program. Often time's high school 
programs run for shorter durations of a few weeks. College-aged exchange students typically spend a semester to a year abroad, but there are also shortterm programs that last a few weeks during summer or winter breaks during the academic year.

Benefits of joining a study abroad program. Based on the survey developed at Swiss University, there are three primary benefits from study abroad. First is improving knowledge of a foreign language (79.8\%). An appeal to improve their academic knowledge takes in second place $(69.8 \%)$. The third is determining beneficial connections (18.6\%). The result showed that the essential benefits of study abroad are to improve a foreign language. Another one is to get academic knowledge. The last as about the connection is not considered necessary. In other research There are some benefits of study abroad program such as :

Enhancing Cultural Knowledge. One and another country has a different language, social life, and communities in different communities, forcing students to get used to a new community. That situation will also force a student to make a friend and build communication with the people around them. When the student starts to unite with a new community, he will find a different culture and history. After a period of time, international sojourners' cultural knowledge of host countries will be enhanced (Lee, 2009) [11].

Heightening Intercultural Awareness. Far away from family and friends with a different culture, language, community, and social life, it is challenging for the student. For the first time, the student will feel uncomfortable with the new life. They will begin to face a life that differs from the usual but, after a long time, the student becomes familiar with a new social life and home life. The student will get used to a new life. The student will feel comfortable with a new social life and home life. Students' study abroad programs will then enhance their intercultural awarenesss (LarzénÖstermark, 2011) [5].

Heightening Self-Understanding. In general, it is to give the student rich experiences. Life in another country with a different history, economy, and cultural pattern make students learn about those differences. That is a chance for students to have a lot of experience and to understand their own selves. The students will begin to learn about the history, economy, and cultural patterns of another country. The students will get used to the history of that country. The student will adjust to the economy in that country. For the last, the student will adapt to the cultural pattern of that country. These whole experiences will make them understand that they are parts of a bigger world; hence, their selfunderstanding and personal views could be improved [4].

\section{METHODOLOGY}

In conducting the present study, a qualitative research approach was employed. In-depth interviews were done with three pre-service teachers who participated in various study abroad programs to collect the data. All participants were English as A Foreign Language (EFL) pre-service teachers: Jasmine, Rossy and Lily. Pseudonyms were used to ensure participants' confidentiality. All participants had experienced a study abroad program in the form of student exchange. The study abroad programs were all managed by the university where they enrolled. The program lasted for one up to two semesters. During the programs, they all needed to take classes in host universities in EFL countries.

The first participant, Jasmine, was a junior student during the data collection and had her study abroad program in China for one semester. The second participant, Rose, was a senior student and had her study abroad program in Taiwan. The third participant, Lily, was also a senior student and had her Spain study program for one year. None of them spoke the national language in the host institution, and therefore they all mainly used English to communicate with their peers during the program.

\section{FINDING AND DISCUSSION}

\subsection{Improving knowledge of a foreign language}

The results of the interview with three participants revealed that there are some benefits to study abroad. One of those benefits is improving knowledge of a foreign language. Those all three participants stated that one of the benefits of study 
abroad is improving knowledge of a foreign language. As Lily said, "Study abroad improves English language proficiency, although the country is not an English country" (P1.35). Besides the second participant, Jasmine also stated that study abroad improved knowledge of a foreign language. In the interview, "Increase vocabulary in either English or Taiwanese because when communicating, we use two languages at the same time" (P2.4). The third participant, Rose, agreed that study abroad improved knowledge of a foreign country. She said, "we can learn a mandarin language in the native country" (P3.6).

Based on the result, the three participants had the same agreement. Christi stated that study abroad programs' most benefits-improved knowledge of the foreign country. Those three participants agreed that study abroad improved knowledge of a foreign language. They stated those statements based on their experiences in study abroad. From their participation in study abroad, they learn about a different language. One of the participants in improving English proficiency and the other is to learn about the Mandarin language. In line with this, Bouchard (2017, p. 35) suggested that one of ICC's essential components is "awareness of strategies to present one's native culture, and inquire about other culture."[10].

\subsection{Personal Growth}

Another benefit of student exchange is personal growth. The statements of some participants prove this result. Lily said, "With the difference in school life and home life, train independence" (P1.13). Likewise, another participant also said the same thing while interviewing. Jasmine said, "Training the independence because everything is doing individually" (P2.7). Rose also said in the interview, "Learn to live independently, not to depend on other people" (P3.8). Those statements prove that the three participants agreed that participating in study abroad training selfindependence.

The result proves that one of the benefits of the study abroad program is training self-independence. Brown (2009) said that personal growth is one of the benefits of internaational sojourn [4]. Students who usually depend on their parents or siblings learn to take care of their needs in daily life. Students who usually need the help of a friend or teacher in the academic field learn to handle them. Every problem that exists makes students forced to find their solution.

\subsection{Cultural Knowledge}

The other component of ICC that was developed through students' study abroad experiences is their cultural knowledge. This finding is proven by the statements of all three participants of ther study. Lily noted that her experience has made her to "start to see different cultures directly" (P1.31). Jasmine also shared her views, "Different countries with the different backgrounds of history, economics and culture make want to learn about those differences to adding knowledge "(P2.8). Jasmine added in the interview that her international exposure during her study abroad programs provided her with "more insight into language, culture, mindset, how to live, and how to learn" (P2.22). Rose also stated, that her study abrod program help her develop more worldly understanding of other countries (P3.5).

This finding on cultural knowledge resonated with the ICC model proposed by Byram (1997) [7]. One of the major components of ICC competence which could be achieved through intercultural encounter is knowledge (savoirs) of social groups and their products and practices in one's own and in one's interlocutor's country, and of the general processes of societal and individual interaction [7].

Pre-service teachers' enriched knowledge is important for their future teaching career. Teachers' personality traits, such as being knowledgable and open-minded were deemed by students to be some of the characteristics of effective teachers [12]. Preservice teachers' exposure to world knowledge and various culture may help them develop their effectiveness as teachers.

\section{CONCLUSION AND PEDAGOGICAL IMPLICATION}

The research findings suggest that the research participants' intercultural communicative competence was developed during their study abroad program. The development includes their foreign language knowledge improvement, critical thinking development and cultural knowledge development. These findings resonate with the ICC 
models developed by Byram (1997) [7] and Bouchard (2017) [10].

There are several pedagogical implications based on the research findings. Firstly, teacher training institutions need to consider encouraging pre-service teachers to embark on study abroad programs whenever possible. Their involvement in study abroad programs may be able to expose them with intercultural interactions and subsequently develop their ICC competences.

Secondly, teacher educators may consider integrating intercultural experiences for their students, either offline or online. Exposing future teachers with first-hand encounters to other culture may help them develop their intercultural competences.

However, despite the encouraging findings of the present study, it should be noted that the findings may not be generalizable to other contexts. Additionally, small number of participants of the present study may also be taken into account. Therefore, future research may consider condicting a larger size study to generate generalizable results. Additionally, studies on ICC and study abroad program for pre-service teachers may also be conducted in various contexts to gain deeper insights from various contexts. Finally, further studies that employ more current models may also provide richer insights on pre-service teacher ICC.

\section{REFERENCES}

[1] Timpe, V. (2014). Assessing Intercultural Language Learning: The Dependence of Receptive Sociopragmatic Competence and Discourse Competence on Learning Opportunities and Input. Language Testing and Evaluation, 31. Frankfurt am Main, DEU: Peter Lang AG

[2] Messer, D., \& Wolter, S. C. (2007). Are students exchange Worth it? Higher Education, 670-685.

[3] Jackson, J. (2008). Globalization, internationalization, and short-term stays abroad. International Journal of Intercultural Relations, 32(4), 349-358.
[4] Brown, L. (2009). The transformative power of the international sojourn: An ethnographic study of the international student experience. Annals of Tourism Research, 36(3), 502-521.

[5] Larzén-Östermark, E. (2011). Intercultural sojourns as educational experiences: A narrative study of the outcomes of Finnish student teachers' language-practice periods in Britain. Scandinavian Journal of Educational Research, 55(5), 455-473.

[6] Mardiningrum, A. (2017). EFL Teachers' linguistic self-concept in a study abroad (SA) Program. Journal of Foreign Language Teaching and Learning, 2(2), 27-37.

[7] Byram, M. (1997). Teaching and Assessing Intercultural Communicative Competence. Clevedon: Multilingual Matters

[8] Arfiandhani, P. (2017). Investigating Language Teachers' Sojourn Experiences: Perspectives on Culture. Journal of Foreign Language Teaching and Learning, 2(1), 44-54.

[9] Kramsch, C. J. (1998). Language and Culture (Vol. 3). Oxford: Oxford University Press.

[10] Bouchard, J. (2017). Ideology, Agency, and Intercultural Communicative Competence. Singapore: Springer. Bamber, P. (2007). The Transformative Power of The International Sojourn: an Ethnographic Study of The International Student Experience. Education for Sustainable Development: Graduates as Global Citizens, 10-11.

[11] Lee, J. F. (2009). ESL student teachers' perceptions of a short-term overseas immersion programme. Teaching and Teacher Education, 25(8), 1095-1104.

[12] Murtiningsih, S. R. (2017). Moody Teachers Ruin My Motivation: An EFL Student's Voice on Effective EFL Teachers. Journal of Foreign Language Teaching and Learning, 2(1), 1-8. 